Témoigner

Getuigen
Témoigner. Entre histoire et mémoire

Revue pluridisciplinaire de la Fondation Auschwitz

$125 \mid 2017$

Histoire et mémoire de la persécution des homosexuel·le's par les nazis

\title{
Van de Vriendenkring van Gewezen Politiek Gevangenen in Silezië tot de Stichting Auschwitz: bouwen aan de Belgische gedachtenis
}

De l'Amicale des ex-Prisonniers Politiques de Silésie à la Fondation Auschwitz: constructions de mémoires en Belgique

\section{Sarah Timperman}

Traducteur : Gorik de Henau

\section{OpenEdition}

Journals

Édition électronique

URL : https://journals.openedition.org/temoigner/6579

DOI : $10.4000 /$ temoigner.6579

ISSN : 2506-6390

Cet article est une traduction de :

De l'Amicale des ex-prisonniers politiques de Silésie à la Fondation Auschwitz : constructions de mémoires en Belgique - URL : https://journals.openedition.org/temoigner/6532 [fr]

Éditeur :

Éditions du Centre d'études et de documentation Mémoire d'Auschwitz, Éditions Kimé

\section{Édition imprimée}

Date de publication : 1 octobre 2017

Pagination : 118-129

ISBN : 978-2-930953-01-4

ISSN : 2031-4183

Référence électronique

Sarah Timperman, «Van de Vriendenkring van Gewezen Politiek Gevangenen in Silezië tot de Stichting Auschwitz: bouwen aan de Belgische gedachtenis», Témoigner. Entre histoire et mémoire [Online], 125 | 2017, Online op 24 décembre 2021, geraadpleegd op 04 février 2022. URL: http:// journals.openedition.org/temoigner/6579 ; DOI: https://doi.org/10.4000/temoigner.6579 


\section{Van de Vriendenkring van Gewezen Politiek Gevangenen in Silezië tot de Stichting Auschwitz: bouwen aan de Belgische gedachtenis \\ $\triangle$}

witz werd en de voorloper is van de huidige Stichting Auschwitz - in deze evolutie past. De vereniging had zowel 'politiek' als 'Auschwitz' in haar naam, en bevond zich dus op het snijvlak van de twee belangrijkste gedachtenislijnen in België. Wat was haar precieze plaats in dit gefragmenteerde herinneringslandschap? Om die vraag te beantwoorden baseren we ons op de archieven van de Silezische Vriendenkring (bewaard door de Stichting Auschwitz) en op interviews met de leiders daarvan uit de vroege jaren negentig.

OPRICHTING VAN DE VRIENDENKRING VAN GEWEZEN POLITIEK GEVANGENEN IN SILEZIË (1946)

Onmiddellijk na de oorlog werden heel wat vriendenkringen opgericht om de belangen van de teruggekeerde gedeporteerden te verdedigen. Een daarvan was de Vriendenkring van Gewezen Politiek Gevangenen in Silezië (Polen), waarvan we een eerste spoor terugvinden in oktober $1945 .^{2}$ Deze informele groep overlevenden wilde meer weerklank geven aan het Belsenproces, waar een veertigtal SS'ers uit de kampen Auschwitz en Bergen-Belsen terechtstond. Zes maanden later, op 31 maart 1946, hielden de leden van de vereniging in het Vlaamsch Huis op de Bruselse Grote Markteen algemene vergadering warr de 'Vriendenkring van Gewezen Politiek Gevarienen Politiek Ge en Externe Commando's het licht zag. De pas opgerichte vereniging definieerde haar programma als volgt: bijdragen tot het onderdrukken van oorlogsmisdaden

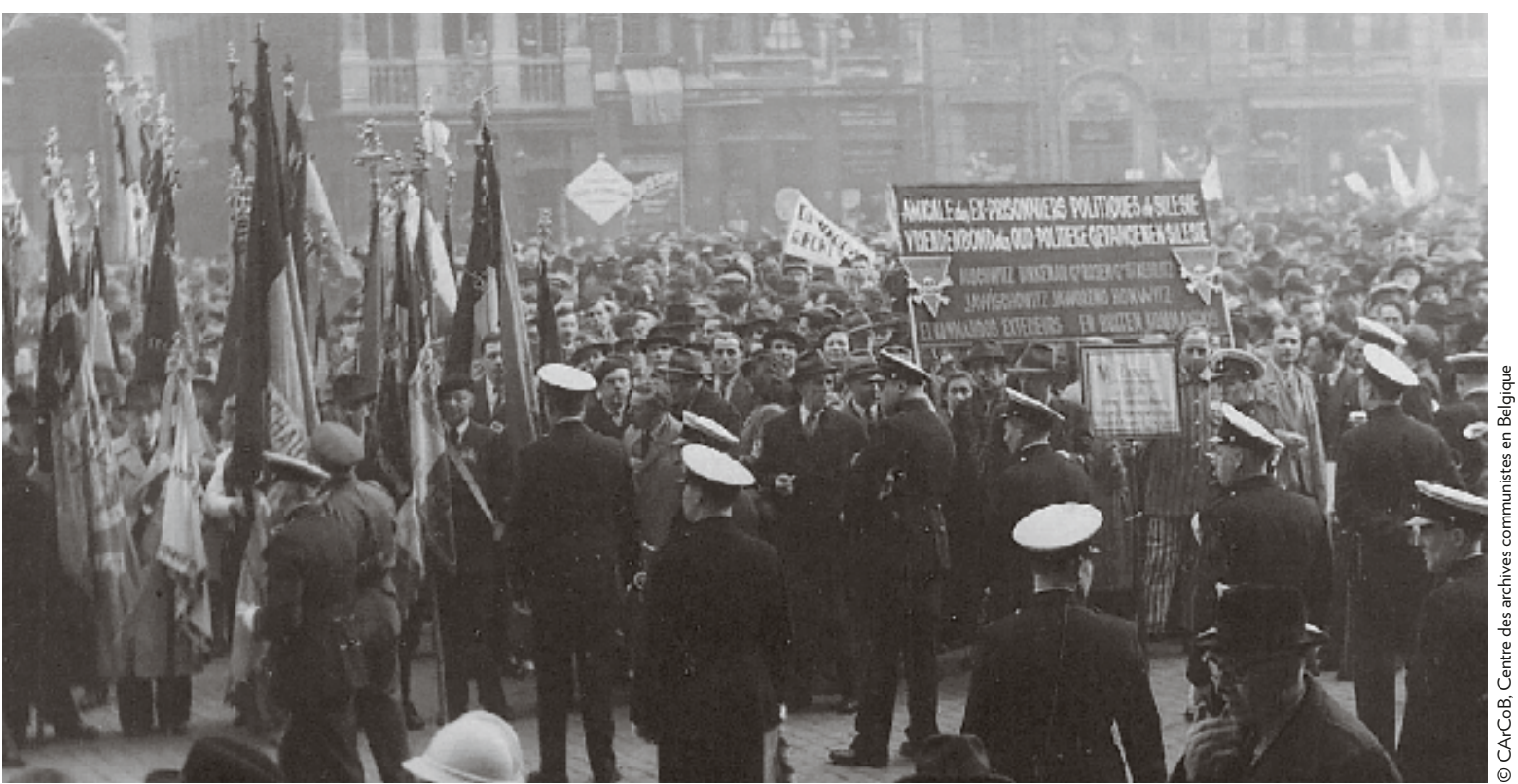



(3) Raymond Rivière
(05/08/1908-12/10/1951):
licenciaat economische wetenschappen, hoge ambtena
van de RVAW (Rijksdienst voor Arbeidsbemiddeling en Werbloosheidd tot zijn
a anhouding op 2 april 1943. aanhouding op 2 april 1943. Vught, Sachsenhauausen, Gross-
Rosen en Ravensbrück. Van Rosen en Ravensbrück. Van
april 1946 tot april 1947 lid van communistisch minster van Bevoorrading. Vgl. zinn korte levensbeschrijining door José
Gotovitch op Maitron en ligne (http://maitron-en-ligne.univ(4) Bijvoorbeeld Alphonse Roe(4) Bijvoorbeeld Alphonse Roe-
landts (ondervoorzitter), René Giets (secretaris-generaal), Paul Mevisse (adjunct-secretaris),
Gustave Fossaert (penningmee Gustave Fossaert (pen
ter). Vgl. hun biografie in
bovenvermelde studie.

(5) Paul Halter (10/12/192030/03/2013): Joods verzetsstrijder. Was korpsshef bij de
Partisans Armés, werd in juni 1943 aangehouden, opgesloten vechelen gedeporteerd In 20 septembr 194 aa Auschwitz werd hij ingedeeld bi Terug in België ging hij werken lerug in Belgie ging hij werken
voor de AlVG en trad hij toe tor de Vriendenkring van Gewezen Politiek Gevangenen in Silezieie
warvan hij in 19655 secretaris werd en in 1976 voorzitter. Vgl. Zijn biografisch dossier bi
Stichting Auschwitz. (6) Dossiers FOD Sociale
Zekerhid, Directie-generaal Zekerheid, Directie-generaal SVG-dol 7789 e en SVG-
PP18228/5343).

(7) Claire Duysburgh (08/01/1899-23/11/1980): verzets12 maart 1943. Gedeporteerd 12 maart 1943. Gedeporteer Strehlitz. Ging na terugkeer ut de kampen werken voor het
ministerie van Wederopbouw en tot de jacht op collaborateurs, de rechten verdedigen van de voormalige politiek gevangenen en hun families, en hun morele en materiële steun bieden.

De vergadering benoemde Raymond Rivière, communistisch activist en overlevende van het Gross-Rosenkamp, tot voorzitter van de vereniging. ${ }^{3}$ Er werd ook een commissie aangesteld met gedeporteerden uit de kampen Gross-Rosen en Gross-Strehlitz, waarvan de meesten uit de gelederen van het Onafhankelijkheidsfront en de Partisans Armés kwamen ${ }^{4}$ De Silezische Vriendenkring vormde geen uitzondering binnen het geheel van naoorlogse verenigingen van overlevenden, Parij angezien de genwoordigd waren. Bovendien was de Silezische Vriendenkring, net als de andere vriendenkringen, aanvankelijk uitsluitend een groepering van voormalige politiek gevangenen, want de gedeporteerde Joden onder hen waren lid vanwege hun activiteit als verzetsstrijder. Er bestond op dat ogenblik geen specifieke vereniging die zich inzette voor de rechten van slachtoffers van deportatie op raciale gronden; zij vormden een geïsoleerde en verarmde minderheid en hun eerste opdracht bestond erin hun leven weer op te bouwen en hun plaats in de Belgische samenleving opnieuw in te nemen. Organisaties voor zelfhulp en groepsvorming die in de schoot van de Joodse gemeenschap ontstonden, bijvoorbeeld Solidarité Juive en AIVG (Aide aux Jsrálites Victimes de la Guerre), zo den hen helpen bij hun re-integratie en Israélites Victi ine en culturele rol vervullen.

Om alle overlevenden van de kampen gelijk te behandelen volgens het unieke 'criterium van het lijden' werd op 6 april 1946 onder auspiciën van de minister van Oorlogsslachtoffers de NCPGR (Nationale Confederatie van Politiek Gevangenen en Rechthebbenden) opgericht. De dag na het stichtingscongres nam de Silezische Vriendenkring, die natuurlijk lid was, deel aan een grote nationale bijeenkomst op de Grote Markt in Brussel. Op die manier kwamen de verschillende nazislachtofferorganisaties en de vriendenkringen van kampoverlevenden bijeen. Die eenheid werd bekrachtigd door een wet die de officiële status van politiek gevangenen regelde en stipuleerde dat alle verzetsstrijders en gedeporteerden op raciale gronden volsen hetzelfde criterium behandeld moesten worden. Mar het project werd a ver door de katholieken en vaderlandslievende verenigingen, die vonden dat alleen de verzetsactiviteit een criterium mocht zijn. We weten niet wat het standpunt was van de Silezische Vriendenkring over deze kwestie, maar uit getuigenissen blijkt toch dat er een verhitte discussie heeft gewoed. Sommige leden waren gekant tegen de eengemaakte status, terwijl anderen vonden dat alle overlevenden minstens moesten kunnen genieten van de status van politiek gevangene. Met de op 16 maart 1947 goedgekeurde wet haalde die laatste, halfslachtige maatregel het uiteindelijk: een soort 'Belgisch' compromis waardoor alle begunstigden dezelfde materiële rechten kregen, maar alleen de verzetslui aanspraak mochten maken op de status van politiek gevangene. De Joodse slachtoffers werden dus niet officieel erkend en konden alleen genietenvaneen automatische matregelvan het ministerie voor Oorlogshact als ze konden bewijzen dat ze bij het verzet waren of de Belgische nationaliteit bezaten. Van de uit België gedeporteerde Joden waren evenwel 95 procent vreemdelingen
(Lagrou 2003, 210-215). De Belgische overheid besefte dus hoegenaamd niet dat voor de Joodse overlevenden specifieke maatregelen nodig waren. Ook de publieke opinie interesseerde zich nauwelijks voor de slachtoffers van de Endlösung en net als de pers was ze meer begaan met het roemrijke lot van de verzetsstrijders. Het Fort van Breendonk kreeg een symbolische status en trok alle aandacht naar zich toe, ook vanwege de Silezische Vriendenkring die deelnam aan de jaarlijkse bedevaart ter plaatse. Paul Halter ${ }^{5}$, de toekomstige voorzitter van de Vriendenkring vertelt:

We vonden toen dat Breendonk ruimschoots volstond als symbool van de deportatie en het verzet in België. Uiteindelijk hoefden we niet per se de nadruk te legsen op Auschwitz en waar dat precies voor stond.

De Dossinkazerne, nochtans ook een symbolische plek, werd op geen enkele militaire bestemming. Onmiddellijk na de oorlog was de gedachtenis dus grotendeels patriottisch van aard, terwijl de Jodenvervolging decennialang uit het collectieve geheugen verdween.

De Silezische Vriendenkring verloor in oktober 1951 haar eerste voorzitter bij een ongeval. Raymond Bivière werd opgevolgd door Adolphe D'Hont ${ }^{6}$, ingerieur, Gross-Rosen, maar in tegenstelling tot zjn voorganger geen lid van de communistische partij. Daarnaast werden Claire Duysburgh en Mariette Altorfer ${ }^{8}$ benoemd tot ondervoorzitters. Beiden zouden zich in de volgende twintigjaar tot belangrijke figuren van de Vriendenkring ontpoppen.

In april 1955 nam de Silezische Vriendenkring op uitnodiging van een Poolse verzetsvereniging de Belgische delegatie mee naar Auschwitz om er deel te nemen aan de herdenkingen in het raam van de tiende verjaardag van de kampbevrijding. Er vond een plechtigheid plaats met duizenden mensen uit zeventien landen. Deelnemers bezochten het kamp, legiden een bos bloemen neer en elke nationale delegatie mocht een toesprak houden. Die van de Belgische delegatie was tekenend voor die tijd, want de Shoah-slachtoffers bleven in de schaduw van de verzetshelden en het unieke karakter van de Joodse genocide werd verhuld. ${ }^{9}$ Maurice Goldstein ${ }^{10}$ die later een rol zou spelen in de Vriendenkring, was aanwezig bij de plechtigheid:

Dat een en ander in de doofpot werd gestopt heeft ons niet geraakt. Voor de overlevende Joodse gevangenen [...] die voor het eerst naar Auschwitz terugkeerden, was het ideaal van de internationale solidariteit belangrijker voor de toekomst van Europa en de wereld dan het feit dat de meeste slachtoffers in de nazivernietigingscentra Joden waren. (Goldstein 2016, 203)

Claire Duysburgh vergeleek het ook met een doofpotoperatie toen ze een paar maanden later in het gastenboek van het Auschwitzmuseum schreef: 'Ontroerd hebben de Belgen een moment stilte in acht genomen op de plek waar hun lotgenoten uit (dienst Oorlogslachtoffers).
Werd ondervoorzitter van de NCPGR, waarvan ze de Brus-
selse afdeling voorzat. Vgl. haar (2006, 229). (8) Mariette Génard
(24/04/1914-15/03/1998) echtgenoot van Emile Altorfer
Communistisch activist lid var het Onafhankelijkhididfront en
het Armée Belge des Partisans. Door de Gestapo a angehounden naar de gevangenis van Essen en geinterneerd in achtereenvolgen

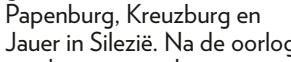
werd ze weer onderwijzeres en engageerde zich in de Politiek Gevangenen in Silezië. Vgl. haar korte levensbeschrijving

(9) 'Van de tienduizenden Belgen
die door het nationaalsocialisme uit hun land werden weggerukt terug, minder dan vijf procent.
Dit bloedbad is een bewiis van de wreedheid van het nazisme. van Breendonk - waar verzetsvaderland, werden opgessoten en terechtgesteld - voelen politiek
gevangenen uit heel Belgie zich één met alle slachtoffers van de nazidwingelandii' (fragment uit de verklaring van de Belgische
delegatie) - CarCob Fonds Henri Buch, farde 37.

(10) Maurice Goldstein
(27/01/1922-06/10/1996): op 3 september 1943 samen
met zijn gezin aangehouden tijdens de tweede grote razzia in Brussel. Met het twintigste transport van Mechelen naar
Auschivtz gevoerd, waar hij werd
ingedeeld bij het Fürstengrubevemmando en daarna als zerpleger ging werken. $\mathrm{Na}$ studerde hij geneeskunde. Hij werd diensthoofd in het $\mathrm{Sin}$ -
Pietersziekenhuis in Brussel Pietersziekenhuis in Brusset
en engageerde zich in het Internationaal Auschwitz Comite, 
achttien landen leden en stierven omdat ze vrij wilden zijn."11 Auschwitz, tegenwoordig een symbool van de deportatie en uitroeiing van de Joden, was toen maar een halte op de eerste reis van de Silezische Vriendenkring in september 1955. De belangrijkste doelstelling was een 'pelgrimstocht naar Gross-Rosen', een concentratiekamp op ongeveer zestig kilometer van Wroctaw (het vroegere Breslau) in het westen van het huidige Polen. Na Gross-Rosen gingen de deelnemers (25 personen, overlevenden vergezeld van familieleden) naar Świdnica om zich te bezinnen bij het monument voor de politiek gevangenen. Daarna ging het naar Krakau, Auschwitz en Nowa Huta met zijn 'Leningieterij', en de reis werd afgerond met een bezoek aan Warschau.

Het ging natuurlijk in de eerste plaats om een 'pelgrimstocht' ter nagedachtenis van de overledenen, maar toch was de Poolse reis van de Silezische Vriendenkring overduidelijk doordrongen van sympathie voor het communistische regime in Polen, zoals ook blijkt uit het lange verslag van Claire Duysburgh. ${ }^{12}$ Net als bij de oud-gedeporteerden, waar als gevolg van de communistische aanwezigheid grote spanningen ontstonden, mondde dit alles bij de Silezische Vriendenkring uit in het vertrek van de voorzitter, die volgens Mariette Altorfer 'niet langer het woord wilde nemen in een vriendenkring die volgens hem in politiek opzicht niet verdedigbaar was'. Medio 1956 volgde Mariette Altorfer dus Adolphe D'Hont op. Renée Van Hasselt ${ }^{13}$ werd angesteld als national secretaris, terwijl Claire Duysburgh ondervoorzitter bleef en zo het vrouwelijke trio aan het hoofd van de organisatie vervolledigde.

HET YOORZITTERSCHAP YAN MARIETTE ALTORFER EN DE ANTIEASCISTISCHE BOODSCHAP VAN DE SILEZISCHE VRIENDENKRING (1956-1976)

Onder het voorzitterschap van Mariette Altorfer vonden zes reizen of beter gezegd ‘bedevaarten' plaats naar de kampen in Silezië. Het aantal deelnemers wa relatief beperkt: nauwelijks vijftien personen, hoofdzakelijk overlevenden en hun familieleden. Tijdens de reizen werden de kampen Gross-Rosen, Gross-Strehlitz, soms Jauer en Auschwitz bezocht en ook toeristische plekken als Krakau en Warschauwerden anngedan. Elkbezoek

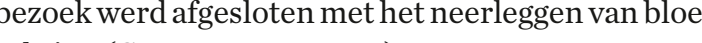
en en vlag van de Vriendenkring (Gregory 1992, 13-17).

Nadat de politiek gevangenen hun officiële status en nationale erkenning gekregen hadden, stak de Vriendenkring veel energie in herdenkingsactiviteiten: verjaardagen van de bevrijding van de kampen, pelgrimstochten naar Breendonk, het aanwakkeren van de vlam van de onbekende soldaat, deelname aan plechtigheden van andere vriendenkringen, het inhuldigen van gedenkplaten en monumenten enzovoort. De Vriendenkring was aanwezig bij (bijna) alle plechtigheden, met de vaandeldrager op kop. Naast haar 'herdenkingsverplichtingen' organiseerde ze ook activiteiten als debatten, filmvertoningen, theatervoorstellingen en concerten, om zo fondsen te werven voor de eigen werking en sociale werken.

De Vriendenkring verzette zich ook tegen het vrijkomen van voormalige collaborateurs en hielp bij de klopjacht op nazimisdadigers. In 1947 al was ze aanwezig op het proces tegen Rudolf Höss, de voormalige bevelhebber van Auschwitz, die van
11 maart tot 2 april terechtstond voor het Poolse hooggerechtshof. Tientallen getuigen en voormalige gevangen van diverse nationaliteiten waren opgeroepen om te getuigen. Raymond Rivière begeleidde toen de Belgische delegatie als voorzittervan de Silezische Vriendenkring Tie de Sile jaar later be Viden kring tusen in Belgièverijvende slachtoffers en de West-Duitse justitie. Tijdens het vooronderzoek van het proces tegen Carl Clauberg, naziarts in Auschwitz, zocht de Vriendenkring op verzoek van het Duitse

parket naar oud-gevangenen uit blok 10 in Auschwitz, waar medische experimenten plaatsvonden. Jammer genoeg moest Carl Clauberg geen verantwoording afleggen voor zijn misdaden omdat hij overleed in augustus 1957, een paar weken voor hij in de bekla me de beklaagdenbank antwoordelijk voor het vinden van getuigen in België bij het proces in Frankfurt, dat bekend staat als het 'tweede Auschwitzproces' en plaatsvond van 20 december 1963 tot 19 augustus 1965. Omdat het openbaar was, kwam het grote publiek meer te weten over de werking van het concentratiekamp en de uitroeiing. Samen met het proces tegen Eichmann (1961) zorgde het Frankfurtproces voor meer bewustwording over de omvang van de Joodse genocide. In België dateerden de eerste studies over de Jodenvervolging eveneens van de jaren zestig. Toch zou het nog een tijd duren eer het land de omslag maakte, want de herinnering aan de oorlog werd nog steeds bepaald door politieke en communautaire onenigheid (Benvindo \& Peeters 2012, 231).

Tot de andere opdrachten van de Vriendenkring behoorde belangenverdediging oor har lo voor har ledne ze infor den. Toen het bedrijf IG Farben in 1957 werd verplicht tot schadeloosstelling van oud-gevangenen uit Monowitz, een werkkamp dat afhing van Auschwitz, adviseerde de Silezische Vriendenkring over de te volgen procedure. Dit was opnieuw het geval in december 1959, toen een compensatieakkoord werd bereikt tussen de Jewish Claims Conference ${ }^{14}$ en de firma Krupp. De voormalige gevangenen van Auschwitz, Gross-Rosen en satellietkampen die een aanvraag tot schadevergoeding wilden indienen konden dit doen via de Vriendenkring.

Als gevolg van de Duitse wetten betreffende de vergoeding van Joodse slachtoffers werd in België in februari 1956 een nieuwe vereniging van gedeporteerden offers opgerion Joodse Gedepere hoogte een concurrent van de Silezische Vriendenkring wat vragen deed rijzen en

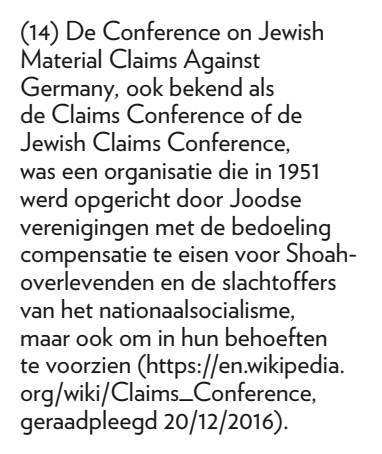

- Inhuldiging van het in Auschwitz, 16 april 1967 

(15) Audio-interview mot
Rene Raindorfor $02 / 29 / 1992$.
René Raindorf (22/12/1918-. O2/01/1/1998) : communistisch en
snndical activist. Lid van het

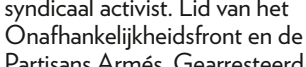

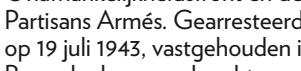
Breendonk, overgebracht naar
de Dossinkzaere en in april 1944 met het 24ste transport naar Auschivitz gedeporporterd har Hij werd

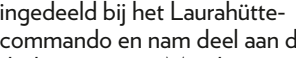
dodenmars naar Mauthausen,
Vgl. zijn levensbeschrijuing in

(16) Jacques Isrä̈l Goldstein werd op 4 april 1944 met $h$ 24ste transport van Mechelen
naar Auschwitz gedeporteerd. Hij genoot niet de status van politiek gevangene. Zie FOD
Sociale ZZkerheid - Directiegeneraal Oorlogsslachtoffers
(dossiers SVG-doo31403,
SVG-PP 18795/3585 et SVG-

wees op verdeeldheid. Een aantal Joodse overlevenden vond dat de Vriendenkring onvoldoende rekening met hen hield en verkoos zich aan te sluiten bij een vereniging die specifiek hun belangen zou verdedigen. Toen de leiders van de Silezische Vriendenkring daar vijfendertig jaar later over geraadpleegd werden, betreurden ze die scheuring. Hoewel ze het idee van de hand wezen dat de Vriendenkring de gedeporteerde Joden niet zou hebben verdedigd, gaven ze wel het volgende toe:

Als de Silezische Vriendenkring niet genoeg deed voor de Joodse overlevenden, dan kwam dat door de toenmalige wettelijke context. [...] We hadden de juridisch-technische middelen niet om hen te verdedigen. ${ }^{15}$

Ze herinnerden eraan dat, in tegenstelling tot de andere vriendenkringen van politiek gedeporteerden, de Silezische Vriendenkring ook openstond voor de Joodse gedeporteerden die niet in het verzet hadden gezeten. Alles wijst er inderdaad op dat Silezische Vriendenkring de toetreding van die laatsten al snel aanvaardde. Die hypothese lijkt bevestigd door het feit dat tijdens de reis van 1955 Jacques Goldstein ${ }^{16}$ (niet erkend als politiek gevangene en op dat ogenblik nochtans penningmeester van de Vriendenkring) en ook Maurice Goldstein aanwezig waren.

Door de oprichting van een alternatieve vereniging werd de Silezische Vrienoverlevenden, hoewel de politiek gevangenen de meerderheid bleven uitmaken. Mariette Altorfer vatte haar voorzitterschap in die zin op:

Ik wilde dat de Vriendenkring haar beleid aanpaste. In het begin had je de gedeporteerGedenkteken voor de Joodse martelaren in
Anderlecht, 19 april 1970

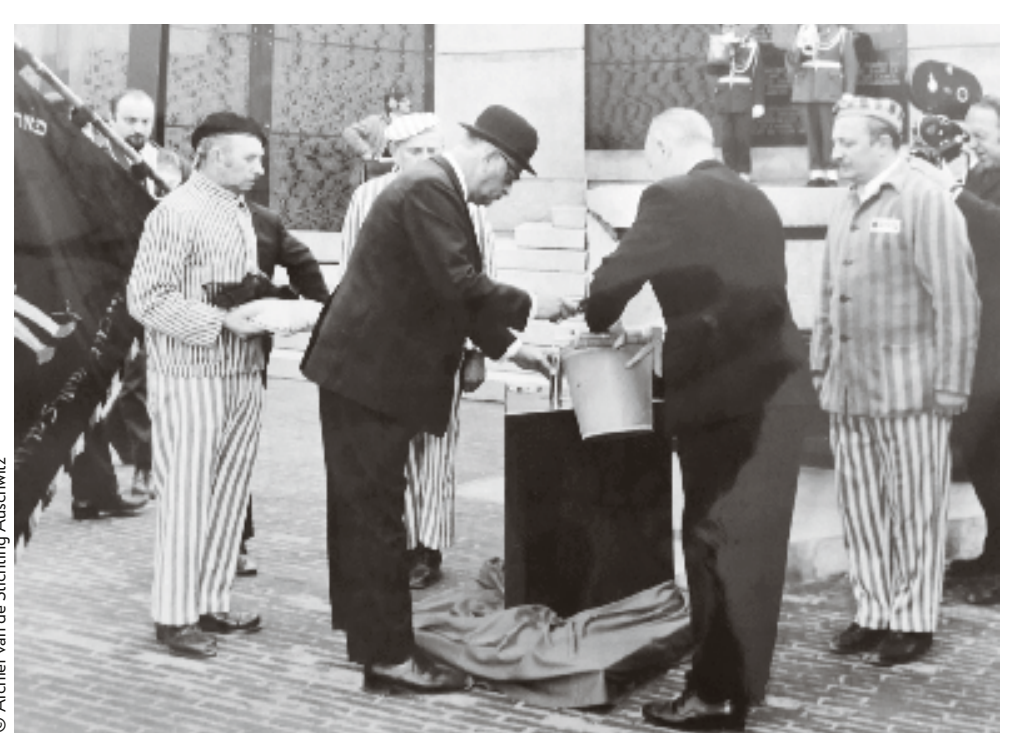
ondat ze het hadden overleefd en met een verzetsverleden. Daarnaast was er die massa mensen die geen verleden in het verzet hadden en die toegang eisten tot de grote gemeenschap van gedeporteerden.

Daardoor ging de Silezische Vriendenkring zich onderscheiden van andere vriendenkringen van politiek gedeporteerden en ze nam een 'gemengde' politiek-Joodse houding aan. Dat betekende ook dat de relatie vertroebelde met de andere verenigingen van politiek gevangenen, die per se het onderscheid fercategorieën wilden handhaven
Toen de Union des Déportés Juifs vroeg om toe te treden tot de Fraternelle des Amicales de Camps [Oud-strijdersbond van de Kampvriendenkringen] werd da geweigerd. Mariette Altorfer beweert dat ze vergeefs trachtte hen te overtuigen:

De Fraternelle opperde dat ze alleen maar de begunstigden van de status waren en dat ze geen politiek gevangenen waren in de strikte zin van het woord. Ik vroeg hun voorzichtis te zijn en argumenteerde dat het criterium van het lijden beslissend was, maar ik heb het niet gehaald. Misschien was ik niet overtuigend genoeg.

Zelfs al kennen we niet het precieze cijfer, een aantal leden van de Silezische Vriendenkring stapte waarschijnlijk over naar de Union des Déportés Juifs of was lid van beide verenigingen.

De oprichting van de Union des Déportés Juifs de Belgique had meteen tot gevolg dat de herdenking van de Belgische Jodenvervolging in een stroomversnelling terechtkwam. De Union organiseerde vanaf 1956 een plechtigheid in de Dossinkazerne en nam ook het initiatief voor het gedenkteken dat op 19 april 1970 in Anderlecht werd ingehuldigd. Met dit monument gingen de Joodse slachtoffers rijkelijk lat de concurrentie an metde politiekgevangenendie al meerdan twintig jar bijeenkwamen in Breendo De Silezische Vriendenkring ho en univis jaar bijectiversalistisch vertoog, wanin de Jodenvervolging niet bij naan werd genoemd; ze had het niet over Joode slact zich aan bij de antifascistische tradite. ze telde de slachtoffers die door uitputting en mishandeling omkwamen in de concentratiekampen op bij zij die onmiddellijk vermoord weren in de vernietigingscentra.

De antifascistische traditie waartoe de Silezische Vriendenkring behoorde was ook pacifistisch. Antifascisme en pacifisme gingen hand in hand tijdens de Koude Oorlogsjaren 1950-1960, toen vrede en de verspreiding van kernwapens centraal stonden in het discours van de Vriendenkring. De vooroorlogse antifascistische strijd vond dus een verlengstuk in de strijd voor de vrede, en het pacifistische vertoog van de Vriendenkring stoelde op de kampervaring. In dit Koude Oorlogsllitoog van de Viencin maat hing de verenigingeen brede anti-Atlantische ideologie aan en nam ze stelling in tegen de herbewapening van West-Duitsland en het vestigen van Amerikaanse bases in Belgiè. Dat was op zich niet verwonderlijk, want heel wat leden hadden uitgesproken communistische sympathieën. De Silezische Vriendenkring was lid van de cryptocommunistische BUVV (Belgische Unie voor de Verdediging van de Vrede) $)^{17}$ en de Acht Meibeweging ${ }^{18}$ die was ontstaan uit publieke bezorgdheid over de atoomdreiging. Zo nam ze deel aan een reeks demonstraties voor de vrede en tegen de verspreiding van kernwapens: optochten en andere pacifistische initiatieven, conferenties en acties voor een internationale détente.

De antifascistische oriëntatie van de Silezische Vriendenkring bleek ook uit de Derte tentoonstling diezebedechtvoor het Belgischepavilioen van het Auschwit-

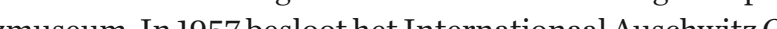
zmuseum. In 1957 besloot het Internationaal Auschwitz Comité (opgericht in 1952
en bestaand uit de leden van de verschillende nationale organisaties) die plek inter-
(17) De BUVV werd in 1949 Kommunistische Partij van met leden van het

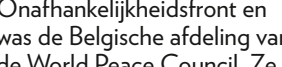
ondernam acties die specifiek verband hielden met de natio verzet tegen de Amerikaanse militaire bases in Belgiè, de Belgische koloniale politieit en
het verlengen van de miltaire

(18) 'Les mouvements de la paix en Belgique', in Courrier
hebdomadaire du CRISP 240 (15)
1964,32 . 
nationaal te maken. Elk land dat daarom vroeg kreeg een tentoonstellingszaal in een van de Auschwitzblokken. In België nam de Silezische Vriendenkring het initiatief voor een nationaal paviljoen (Thanassekos 2008, 177-184). Ze was verantwoordelijk voor de scenografie van de tentoonstelling, die een 'trouw beeld moest geven van het Belgische verzet en de zware prijs die het betaalde om weer vrij te zijn'. Hoewel de Joodse deportatie niet werd gemaskeerd, kwam ze pas op het einde aan bod en vormde ze maar een vijfde van de tentoonstelling. Ze was een onderdeel van de nazimisda ze die als én vehel werd behandeld. Het Belsisch pavilioen vormde daarin geen uitzondering: de tentoonstellingen in de nationale paviljoens waren vooral gericht op de oorlogsgeschiedenis van de afzonderlijke staten, vaak zonde enig verband met Auschwitz en de voornaamste slachtoffers in dat kamp (Brutmann 2015, 101). De realisatie van de Belgische tentoonstelling en vooral de verhuizing naar Polen zouden enige tijd duren, zodat ze pas in 1965 werd ingehuldigd.

In april 1967, twee jaar na de opening van het Belgische paviljoen, ging een omvangrijke delegatie van de Silezische Vriendenkring naar Auschwitz voor de inhuldiging van het internationale monument, een nieuwe herdenkingsplek voor officiële plechtigheden. In België fungeerde de Silezische Vriendenkring als bemiddelaar voor dit project en het stelde eerst en vooral een steuncomité samen Tienjaar lang zocht de Vriendenkring actief naar middelen om het monument te financieren (a) het deed een beroep op de overheid, zamelde geld in, organiseerde gala's, maar het hield vooral culturele activiteiten. Bij de meest prestigieuze darvan kwam David Oïstrakh, een van de beroemdste violisten van de twintigste eeuw, naar het Paleis voor Schone Kunsten in Brussel.

\section{DE SILEZISCHE VRIENDENKRING WORDT}

DE VRIENDENKRING VAN AUSCHWITZ (1976)

In de late jaren zeventig ging het minder goed met de Silezische Vriendenkring. Ze voldeed aan de verwachtingen wat herdenkingen betrof, maar kon zich ma moeilijk vernieuwen moeilijk veni. voornamelijkgerch op voormalige gedeporteerden en hun families, maar de massa 'onwetenden' werd niet bereikt. Dit betreurde Mariette Altorfer, die na twintig jaa als voorzitter vroeg om uit haar functie te worden ontheven. In maart 1976 werd bij de leden een bezinning opgestart. In een rondzendbrief werden nieuwe denksporen voorgesteld, waarover de leden van de Vriendenkring zich moesten uitspreken. De reacties waren positief. Er werd een nieuw, kleiner directiecomité samengesteld onder leiding van Paul Halter, secretaris van de Vriendenkring sinds 1965. Hij zou niet alleen een nieuwe start maken met de herdenkingactiviteiten, maar ook initiatieven nemen om de herinnering aan de concentratiekampen te bewaren en over te dragen. De algemene vergadering van 13 juni 1976 bekrachtiode het ontslag van het dre comé Marette Altorfer en Claire Duysburgh werden erevoorzitte van het oude conite.

ondergedoken oorlogskind, tot secretaris-generaal werd benoemd. Ook Maurice

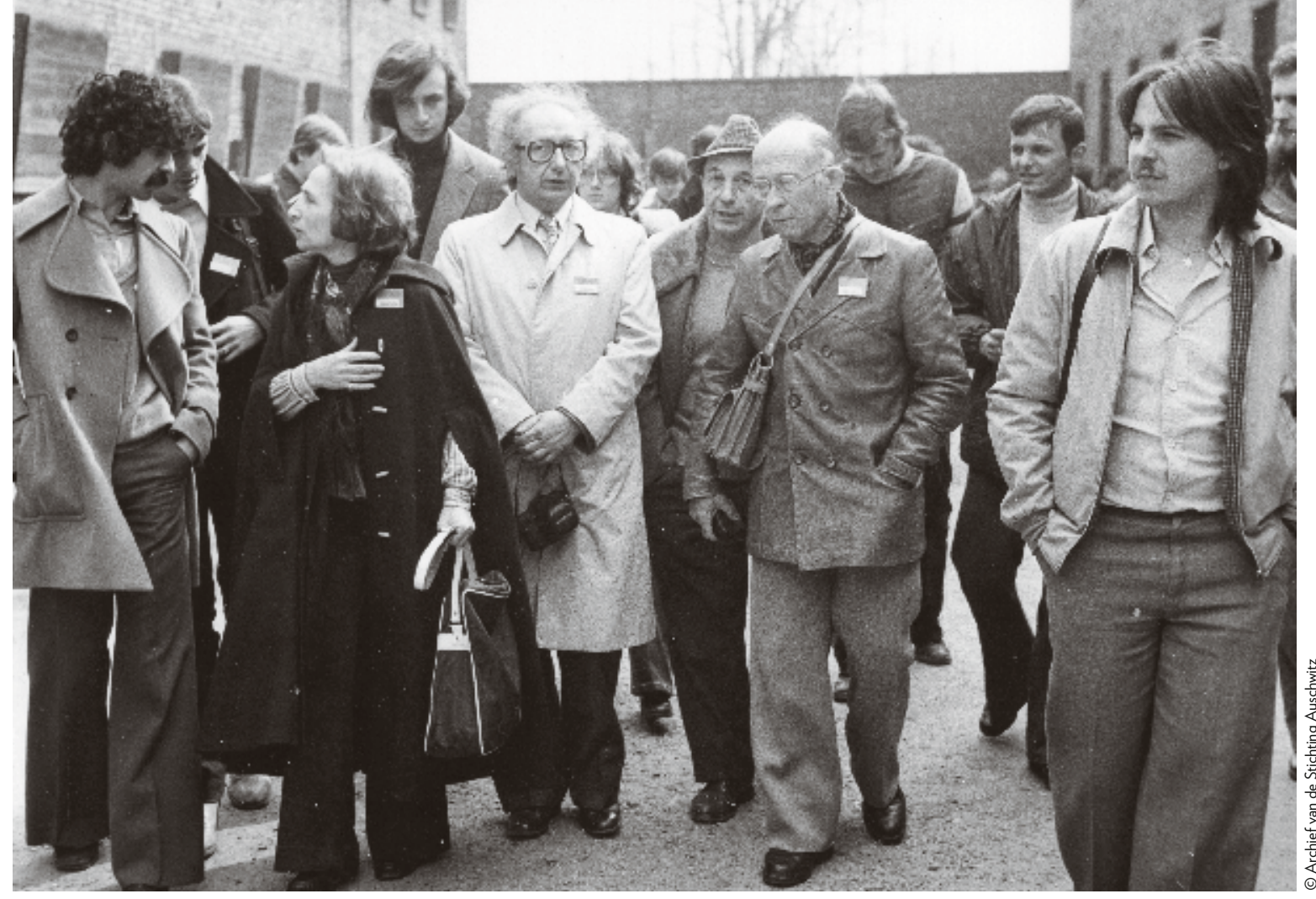

Goldstein, die in 1977 trouwens voorzitter van het Internationaal Auschwitz Comité werd, en René Raindorf speelden in deze nieuwe directie een belangrijke rol.

Om doeltreffender te kunnen strijden tegen Shoah-ontkenning veranderde de Silezische Vriendenkring in oktober 1976 haar naam in 'Belgische Vriendenkring van Gewezen Politiek Gevangenen van Auschwitz-Birkenau, de Kampen en Gevangenissen in Silezië', vaak afgekort tot 'Belgische Vriendenkring van Auschwitz'. De term Silezië verdween naar de achtergrond en in de plaats kwam Auschwitz. René Raindorf bevestigde:

We waren van mening dat we door de opkomst van het negationisme zelfs de naam van de We waren van mening vriendenkring moesten veranderen, want die was niet duidelijk genoeg. We vonden dat we veel meer dan vroeger op Auschwitz moesten inzetten en daarom werd de Silezische Vriendenkring de Vriendenkring van Auschwitz

De naamswijziging kwam er op een ogenblik dat Auschwitz in het collectieve bewustzijn het symbool van de deportatie werd. De leden van de Vriendenkring gingen zich ook steeds vaker profileren als gedeporteerden op raciale gronden. De waarden waarop de herinnering aan het verzet steunde, boetten aan belang in en vooral het communistische verzet verzonk in de vergetelheid.

Ook de Poolse reizen van de Vriendenkring getuigden van die ontwikkeling en ze maak complex was voortaan de enige bestemming en de reizen waren niet langer strikt
- Jongerenreis naar Auschwitz in 1978 Onder begeleiding van (Sarah Goldberg, Maurice Goldstein, Paul Halter en eorges Marechal 
(20) Jarverslag van de Stichting $\quad$ text. Het was de bedoeling een ander publiek te bereiken dan de overlevenden en hun
Auschwitz 1983. familieleden. De eerste reis, waarvan de voorbereiding de Vriendenkring anderhal jaar zoet hield, vond in 1978 plaats; 120 jonge universiteitsstudenten bezochten Auschwitz. Ze werden begeleid door tien overlevenden, die als taak hadden om hun concentratiekampervaring toe te lichten op de plek zelf waar ze opgesloten hadden gezeten. Maar volgens het comité was de balans van de reis niet eenduidig. De studenten waren wel geboeid door de verhalen van de overlevenden en er werden zelf vriendschapsbanden gesmeed. Mar qua kennisoverdrachten vooral het doorgeven van de ervaring was het Comité van oordeel dat de studenten niet over de vereiste bagage beschikten om algemene conclusies te kunnen trekken.

De volgende reis, in 1980, was dan ook gericht op leraren, die als doorgeefluiken voor de herinnering fungeren. Net als bij de vorige reis ging de Vriendenkring van Auschwitz actief op zoek naar fondsen en ze sprak daartoe vooral politici aan, want hun steun was broodnodig. Een zestigtal personen namen deel aan de reis Die duurde een kleine week en hield ook een bezoek aan Warschau en Krakau in Deze formule werd als een succes beschouwd en zou vanaf 1982 jaarlijks worden herhaald door de Vriendenkring van Auschwitz, of om precies te zijn, door haar opvolger de Stichting Auschwitz

\section{BESLUIT: EEN STICHTING NEEMT DE FAKKEL OVER}

In juli 1980 ontstond de Stichting Auschwitz Ze trad geleidelijk in de plaats van de Belgische Vriendenkring van Auschwitz, van wie ze de activiteiten voortzette die gericht waren op het behoud en het doorgeven van de deportatiegedachtenis. Dat steeds meer getuigen overleden, was een probleem dat de Vriendenkring sinds de late jaren zeventig bezighield.

Gemotiveerd door die vrees en omdat ze de strijd met het negationisme wilde
Omdat de Vriendenkringelkjaar getuigen van de kampen ziet verdwijnen heeftze besloten een nieuwe vereniging op te richten, waardoor de volgende generatie voortaan aan haar activiteiten kan deelnemen. In de geest van de oprichters moet de Stichting Auschwitz de komende jaren de fakkel overnemen van de Vriendenkring. ${ }^{20}$

Dit artikel gaat niet over de geschiedenis van de Stichting. Maar we vermelden wel dat ze snel een documentatiecentrum en een bibliotheek zou oprichten, zich zou bezighouden methetontwerp van het tweede Belgisch paviljoen in Auschu colloquia en lezingen zou organiseren en audio- en videogetuigenissen van overlevenden zou vastleggen.

De Stichting Auschwitz werd opgericht toen in België de belangstelling voor de Joodse nazislachtoffers aanzienlijk toenam. Die aandacht valt deels te verklaren door het proces in Kiel (1980) tegen de Duitse ambtenaren die verantwoordelijk waren geweest voor de deportatie in België. Het proces kreeg in ons land zowel binnen als buiten de Joodse gemeenschap veel media-aandacht en steeds meer mensen gingen beseffen hoeveel Belgische Joden er wel waren vermoord. Tegelijk begon de Joodse gemeenschap haar eigen verleden weer nader te bestuderen (Benvindo \& Peeters 2012 , 234). Veel getuigen waren nu bereid om hun ervaring van de bezetting door te geven aan de nieuwe generaties. De Joodse gemeenschap werd zich bewust van het belang van din 1995 het Joods Museum van Deportatie en Verzet werd. Oal toeleggen. Maxime genocide in België, publiceerde halfweg de jaren tachtig zijn trilogie L'étoile et le fusil [nog niet vertaald, noot van de vertaler], die ter zake als het standaardwerk geldt. Hij wees erop dat bepaalde Belgische overheden tijdens de bezetting hadden meegewerkt aan de Jodenvervolging.

Door de opkomst van extreemrechts in de jaren negentig en het toenemende belang van de genocide in het collectieve bewustzijn werd de Jodenvervolging beschouwd als een unieke gebeurtenis. De politieke klasse toonde een groeiende bello belangstelling innering eraan. Dat zorgde voor een onevenwichtige krachtverhouding tussen de verschillende herinneringen. Bij de viering van de vijftigste verjaardag van het einde van de oorlog werd Breendonk omgevormd tot een Human Rights Memorial, terwijl de Vlaamse overheid, die bevoegd was voor de Dossinkazerne als museum-gedenkteken, de kwestie van de mensenrechten primordiaal vond. Bruno Benvindo stipt aan dat 'betreffende de opvoeding tot burgerzin een nieuwe opvatting de overhand [haalt], waarbij de oorlog van 1940-1944 dienstdoet als morele en politieke waarschuwing' (Benvindo 2012, 69). Meer dan een halve eeuw na het einde van de Tweede Wereldoorlog zien we hoe de herinnering aan het krijgsgebeuren plaatsmaakt voor een herinnering die in het teken staat van de mensenrechten. De Joodse volkerenmoord staat centraal terwijl de patriottische en antifascistische herinnering tot het verleden gaat behoren.
BIBLIOGRAFIE

- Bruno Benvindo, 'Autorités du dusce. Memso. (in) disciplinés 2010', Revue belge d'histoir contemporaine $4212,48-77$.

- Bruno Benvindo \& Evert
Peeters Les décombers de Peeters, Les décombres de conflit 1945-2010, Waterloo
Renaissance du Live, 2012. - Tal Brutmann, Auschwitz, Parijs

- Maurice Goldstein, Chroniques Mun rescapé dAuschwitz. Un Brussel: Stichting Auschwitz 2016. - José Gotovitch, Du rouge au tricolore. Résistance et part

- Jocelyn Grégoire, Rapport sur des ex-Prisonniers Politiques Auschwitz-Birkenau, Camps Auschwitz, niet gepubliceerd, 1992. Online beschikbaar op http://www.gregoiretexte/anicalesilesie.htm
(geraadpleegd 31 juli 2017). EÉliane Gubin, Dictionnaire des emmes belges XIXe et XXe Pieter Lagrou, Mémoires azie. Résistants, requis et déportés en Europe occidentale 1945-1965, Parijs/Brussel: IHTP
CNRS/Complexe, 2003 - Jean-Philippe Schreiber,
Ditctionnare biographique des
Juifs de Belgique Figures du judailsme belge, $X X^{\circ}-\chi X^{\circ}$
sieccle, Brussel: De Boeck Yannis Thanassekos, 'Du premier au troisième pavillon
belge à Auschitz $1966-$ 2006)' in Béatrice Fleury \& Jacques Walter (red.), Qualifier
des lieux de détention et de des lieux de détention et de
massacres (2), Metz: Université
Paul Verlaine, 2008, 177-184. 